\title{
Prevalence of suicidality, depression, post-traumatic stress disorder and anxiety among female sex workers: a systematic review and meta-analysis
}

\author{
Juan Manuel Millan-Alanis \\ Universidad Autónoma de Nuevo León \\ Farid Carranza-Navarro \\ Hospital Universitario “Dr. José Eleuterio González” \\ Humberto de León-Gutiérrez \\ Universidad Autónoma de Nuevo León \\ Paloma Calafia Leyva-Camacho \\ Universidad Autónoma de Nuevo León \\ Andrea Femanda Guerrero-Medrano \\ Hospital Universitario "Dr. José Eleuterio González" \\ Francisco J Barrera \\ Universidad Autónoma de Nuevo León \\ Elizabeth Garza Lopez \\ Universidad Autónoma de Nuevo León
}

Erasmo Saucedo Uribe ( $\nabla$ drerasmosaucedouribe@gmail.com )

Hospital Universitario “Dr. José Eleuterio González” https://orcid.org/0000-0002-5082-6105

\section{Research Article}

Keywords: Female Sex Workers, Suicidal Ideation, Suicide, Depression, Anxiety, Post-traumatic Stress, Prevalence

Posted Date: May 11th, 2021

DOI: https://doi.org/10.21203/rs.3.rs-459170/v1

License: (c) (i) This work is licensed under a Creative Commons Attribution 4.0 International License. Read Full License

Version of Record: A version of this preprint was published at Archives of Women's Mental Health on June 10th, 2021. See the published version at https://doi.org/10.1007/s00737-021-01144-1. 


\section{Abstract}

Purpose: To assess prevalence of suicidality, depression, post-traumatic stress disorder (PTSD) and anxiety among female sex workers (FSW).

Methods: A systematic review and meta-analysis was performed. Search strategy was performed in MEDLINE, Scopus, Web of Science, EMBASE, Ovid and Cochrane Central Database from inception until March 2020. Considered for inclusion were cross-sectional studies performed on FSW that assessed prevalence of any of the following: suicide attempt or suicidal ideation, depression, PTSD, or anxiety. Five reviewers independently and in duplicate to select all eligible articles in an abstract and full-text screening phase and to moreover extract information from each study. A binomial-normal generalized linear mixed model was employed to estimate prevalence of the conditions.

Results: From 8,035 studies yielded in the search strategy, 55 were included for analysis. The overall prevalence of suicidal ideation and attempt was $27 \%$ (95\% C.I. 18-39\%) and 20\% (95\% C.I. 13-28\%), respectively. Furthermore, overall prevalence of depression and PTSD was 44\% (95\% C.I. 35-54\%) and 29\% (95\% C.I. 18-44\%), respectively. Eleven studies were classified as high quality.

Conclusion: Findings indicate there is an overall high prevalence of suicidality, depression, and PTSD among FSW. Development of accessible large-scale interventions that assess mental health among this population remains critical.

\section{PROSPERO Registration CRD42020196164}

\section{Introduction}

Worldwide, female sex workers (FSW) represent a highly vulnerable group, frequently exposed to a variety of health hazards, social stigma, violence, and systematic disadvantages (Kessler et al., 2017; Park, J. N., \& Decker, M. R., 2019; Zhang et al., 2014). Also important is the intense psychological stress that some endure, commonly associated to adverse work-related conditions. The environment in which female sex workers live usually has one or several sociocultural determinants that could eventually trigger mental, neurological and substance abuse disorders. Some of these are low social support, inadequate housing, workplace and homeplace violence, among other important factors such as experiencing violence since early childhood. It is important to note that these determinants could be related to both their actual condition and the involved psychopathology. Considering these challenges, high rates of psychological and psychiatric morbidity have been reported among them (Abelson, A. et al., 2019; Coetzee, J. et al., 2018; Patel, et al. 2016; Rael, C. T., \& Davis, A., 2017).

Previous studies have found associations between HIV-related risk behavior and mental health diseases (Fang, Chuang, \& Al-Rae, 2019; Shen et al., 2016; Štulhofer et al, 2017). Moreover, several studies have evaluated depression, anxiety, post-traumatic stress disorder (PTSD) and suicidality in FSW. However, discrepant results suggest that the prevalence of these conditions on FSW remains controversial (MacLean, S. et al. 2018; Ortblad, K. F. et al., 2020; Su, S. et al., 2014; Teixeira, A. \& Oliveira, A., 2017; White, D. et al., 2016; Poliah, V., \& Paruk, S., 2017).

With the growing body of evidence, a synthesis of the available scientific literature could provide a broader and clearer perspective regarding mental health of FSW. With the previous being said, the objective of this study is to estimate the prevalence of suicidality, depression, PTSD, and anxiety among FSW by performing a meta-analysis from studies that stem from more than 25 different countries across 5 continents.

\section{Methods}

This systematic review and meta-analysis adhered to the Meta-analysis of Observational Studies in Epidemiology (MOOSE) statement (Online Resource 1) and a protocol was registered on the International Prospective Register of Systematic Reviews (PROSPERO) (Registration number: CRD42020196164) (Stroup et al., 2000).

\section{Eligibility criteria}

Longitudinal and cross-sectional studies of any language were considered eligible if they met the following criteria: a) their study population was FSW of any age, nationality or working venue; b) they performed an assessment for depression, anxiety, PTSD or stress-related symptoms through a validated rating scale, or evaluated for suicidal ideation or suicidal attempts by direct questions, and c) reported the proportion of these outcomes (in the case of outcomes evaluated by numeric rating scales, according to a pre-specified cut-off point). Studies reporting composite outcomes were excluded.

\section{Search Strategy}

An experienced librarian (LEGL) performed a systematic search strategy on MEDLINE, Scopus, Web of Science, EMBASE, Ovid and Cochrane Central Database from each database inception date until March 2020 without language restriction. Search strategy was comprised of Medical Subject Headings (MeSH) terms and specific keywords involving population (female sex workers) and outcomes of interest (depression, anxiety, post-traumatic stress disorder, suicide ideation and attempt). Grey literature was assessed on opengrey.eu and ntis.gov. The full search strategy is available in Online Resource 2-Search strategy.

\section{Study selection process}

The selection process was performed in an independent and duplicated manner by five experienced reviewers (JMMA, PCLC, FCN, HdLG. and AFGM) on Distiller Systematic Reviews (Evidence Partners) software and was divided into a title/abstract and full-text screening phase. Each phase was pre-piloted to ensure the understanding of the selection criteria and to assess the inter-rater agreement. During the title/abstract screening phase, any disagreement between 
reviewers was passed on to the full-text phase where disagreements were resolved by consensus or intervention of another reviewer. Any non-enligsh published article was translated by study authors.

\section{Data collection process}

All five reviewers independently and in duplicate extracted data from included articles to a previously standardized web-based form. Extracted data included only summary estimates. The following variables were extracted: first author, year of publication, country, and sex work legal status where study was performed, number of participants, age, sex work setting and percentage of HIV positive participants, above mean drug use or exposure to physical/sexual violence compared to general population (United Nations, 2020; WHO, 2020). For scales evaluating depression, anxiety or PTSD, data on whether it was selfreported or rater-administered was obtained as well as cut-off points to determine diagnosis when it applied. For scales that evaluated symptom severity rather than diagnosis, moderate and/or high levels of symptoms were considered as a positive screening for the evaluated outcome. Suicidality was evaluated as direct questions regarding suicidal ideation or attempt during any specific time span. Regarding outcomes of interest, absolute number and proportions were directly extracted or calculated with a simple cross multiplication when either of those was missing. Discrepancies at this stage were resolved by consensus or through intervention of another reviewer.

\section{Quality Assessment}

Quality of individual studies was rated by five reviewers (JMMA, PCLC, FCN, HLG, AFGM) independently and in duplicate using the Appraisal Tool for Cross Sectional Studies (AXIS), a 20-item critical appraisal instrument developed to assess standard of quality of reporting by cross-sectional studies (Downes, Brennan, Williams, \& Dean, 2016). AXIS evaluates quality design (clarity of objectives, design, and rationale for sample size), reporting (consistency between methodology, reported results and conclusions, incorporated measures to account for non-responders) and declaration of funding sources, conflicts of interest and statement of informed consent attainment. Discrepancies were resolved by consensus or arbitration of another reviewer. Since no evidence regarding score classification has been described, a score of 17-20 was classified as high quality, 14-17 as moderate quality and $\leq 13$ as low quality.

\section{Data Synthesis}

Although we consider that our analysis is meant to estimate the pooled proportion rather than the pooled prevalence, we will use the latter term throughout the manuscript for practical purposes. Numeric data was reported as central tendency and dispersion measures, categorical data as frequencies and percentage. Data integration is comprised of a qualitative synthesis and a quantitative synthesis (meta-analysis) where pooled prevalence for each outcome is reported. To estimate prevalence, we used a binomial-normal model for meta-analysis of prevalence via a Generalized Linear Mixed Model (GLMM) (Stijnen, Hamza, \& Ozdemir, 2010). Prevalence estimates were reported as binomial proportions with $95 \%$ confidence intervals. Heterogeneity was assessed with the I2 statistic and Kendall rank correlation coefficient. Levels between $25-50 \%$ were considered as low, $50-75 \%$ as moderate and $>75 \%$ as substantial heterogeneity. Statistical significance was classified as a p value <.05. Meta-analysis was performed in R statistical software version 4.0.2.

\section{Subgroup and sensitivity analysis}

Subgroup analyses were performed by stratifying studies according to sex-work setting (studies performed on streets only, studies performed on combined settings) and sex-work legal status on country where study was performed (legal, partially legal, illegal) (Studies loD; ProCon, 2020). Moreover, sensitivity analyses were performed by stratifying studies according to their quality (high, moderate, low), sample size (higher than 220, lower or equal than 220 ) and sampling method (adequate sampling method, inadequate sampling method). We selected a cut-off point of 220 participants for sample size sub-analysis since it was estimated as the median number of samples. Sampling was considered as appropriate if study reported enough information to generate a conclusion, recruited participants in numerous sites and used any of the following sampling methods: quota, respondent-driven, snowball, peer-referral or probabilistic.

\section{Results}

A total of 8,035 references were screened by title and abstract from which 155 were passed to full-text screening phase. Ultimately, a total of 55 studies, which were performed across 28 countries and 5 continents met the inclusion criteria (Figure 1) (See Table 1 for studies that met inclusion criteria).

Mean/median age of participants ranged between 20.2 and 38.6 years. A total of 8 (14.5\%) studies recruited participants only from the streets, 2 (3.6\%) only from brothels and the rest of them (81.8\%) recruited them on either a mixed setting or did not provide enough information. Thirteen studies (23.6\%) provided information on proportion of HIV positive participants where it ranged between $2 \%$ and $100 \%$. Above mean drug use and exposure to physical or sexual violence when compared to general population parameters was observed in most studies. Full details regarding study characteristics and outcome measures are available on Table 1.

Eleven studies (20\%) were classified as possessing high quality. Moreover, $33(60 \%)$ and $11(20 \%)$ studies possessed moderate and low quality, respectively. Some consistently deficient domains across studies were sample size justification, categorization and description of non-responders (See Table 1 for the overall quality; see Online Resource 2-Table 1 for full assessment).

Suicide ideation was assessed by 18 studies (32.7\%) evaluating 8,107 individuals where independently of temporality, a prevalence of $27 \%$ ( $95 \%$ Cl $18-39 \%$; $12=98.9 \% ; n=8,107)$ was obtained. Moreover, suicide ideation during the year prior to the survey and ever in their lifetime occurred in $21 \%(95 \% \mathrm{Cl} 10-37 \%$; $=$ $4,366 ; 12=98.9 \%)$ and $34 \%(95 \% \mathrm{Cl} 21-50 \% ; n=3,741 ; 12=98.1 \%)$ of participants, respectively (See Online Resource 2 -Figure 1 for overall prevalence). 
Suicide attempt was assessed in 16 studies (29\%) evaluating 6,166 individuals. General prevalence of suicide attempt according to the reported evidence was of $20 \%(95 \% \mathrm{Cl} 13-28 \% ; n=6,166 ; 12=97.6 \%)$. Analysis by temporality, suicide attempt during the last year and ever in their lifetime occurred in $13 \%$ (95\% $\mathrm{Cl} 9$ $18 \% ; n=2,614 ; \mathrm{l} 2=91.1 \%)$ and $25 \%(95 \% \mathrm{Cl} 15-38 \% ; n=3,552 ; \mathrm{l} 2=97.8 \%)$ of participants (See Online Resource 2-Figure 2 for overall prevalence).

Forty studies (72.7\%) evaluated depression in 17,581 individuals where a pooled prevalence of $44 \%(95 \% \mathrm{Cl} 35-54 \% ; n=17,581 ; 12=99.1 \%)$ was obtained. Studies were divided according to if the scale was self-reported or rater-administered and prevalence of $48 \%$ (95\% C.I. 38-58\%; $n=16,642 ; 12=99.2 \%)$ and $28 \%$ (95\% Cl 13-51\%; n=939; I2=96.8\%) were found for each, respectively (See Online Resource 2-Figure 3 for overall prevalence).

Fifteen studies (27.2\%) evaluated PTSD as an outcome on 3,042 individuals. General prevalence of $29 \%(95 \% \mathrm{Cl} 18-44 \%$; $\mathrm{n}=3,042 ; \mathrm{I} 2=98.06 \%)$ was obtained. When subdivided by patient-reported or rater-administered scales, prevalence of $32 \%(95 \% \mathrm{Cl} 20-48 \% ; n=2,318 ; 12=97.8 \%)$ and 24 (95\% Cl 8-54\%; $n=724 ; \mathrm{I}=$ 97.3\%) were obtained, respectively (See Online Resource 2-Figure 4 for overall prevalence).

Twelve studies (21.8\%) evaluated outcomes encompassing anxiety related diagnoses. Due to the observation of significant heterogeneity between anxiety diagnoses (generalized anxiety disorder, obsessive compulsive disorder, phobias, etc.), pooled analysis of this outcome was not performed, and results are reported qualitatively on Table 2 .

Stratification of studies according to sex work site and legal status of sex work on the country where study was performed revealed a higher prevalence of overall PTSD among street-only sex workers when compared to non-street sex workers or samples with combined settings (59\% [95\% C.I. $50.7-66.8 \%$; $n=1,174$; $\mathrm{I} 2=82.5 \%$ vs. $18.6 \%$ [95\% C.I. 10.3-31.3\%; $n=1,868 ; \mathrm{I}=96.4 \%$; $\mathrm{p}<.001$ ). Furthermore, studies that were performed on countries where sex work is partially legal reported higher prevalence of overall PTSD when compared to countries where sex work practice is legal $(61 \%$ [95\% C.I. 53.2-68.3\%; $n=1,274 ;$ I2= 83.03\%] vs. $12.9 \%$ [95\% C.I. 8.6-19.1\%; $n=1,260 ; 12=85.4 \%] ; p<.001)$. No statistically significant differences were observed among these subgroups regarding depression, suicide ideation and suicide attempt (Extended results on Online Resource 2 Table 2-5).

Studies with inappropriate sampling methods reported a higher prevalence of suicide ideation when compared to studies with appropriate (n, \%) sampling methods (43.1\% [95\% Cl 31.6-55.3\%; $n=758 ; 12=89.2 \%$ ] vs. 18.9\% [95\% Cl 10.3-32.2\%; $n=7,349 ; 12=99.2 \%]$; .026). No significant differences were found when performing sensitivity analyses according to sample size, study quality or sampling methods across outcomes (Extended results on Online Resource 2 , Tables 2-5).

\section{Discussion}

FSW are an extremely vulnerable group susceptible to intense psychological stress derived from multiple health, social, economic, and legal barriers where the exposure to different types of violence during their lifetime also plays a key role in the psychopathology of mental health disorders (Romans et al., 2001; Rössler et al., 2010; H. L. Surratt \& Kurtz, 2012). It comes as no surprise that prevalence for psychiatric symptoms marginally surpasses that of the general population. In addition to the previously mentioned, when comparing them to other similarly vulnerable populations, especially considering trauma-exposed populations, proportions of depression and PTSD are still higher among FSW (Morina, Stam, Pollet, \& Priebe, 2018).

To the best of our knowledge, this is the largest meta-analysis to examine the prevalence of depressive symptoms in FSW, and the only one regarding anxiety, PTSD, and suicidal behavior. Furthermore, our analysis encompasses results from studies performed on more than 25 countries worldwide, which provides a global perspective on this important topic. Our results highlight the significantly elevated prevalence of psychiatric morbidity in FSW. Depressive symptoms were the most amply studied with a pooled prevalence of $44 \%$ from 40 studies and 17,581 subjects. This is staggeringly higher compared to the general population (12.9\%) (Lim et al., 2018). A previous review obtained an estimate of 62\%, although this result was based on only 4 studies (Yuen et al., 2016). Regardless, the occurrence of depressive symptoms is still alarmingly elevated, irrespectively of self-reported or rater-administrated instrument use. Similarly, the prevalence of other outcomes was higher in FSW when compared to general population: PTSD (29.3\% vs $11.1 \%)$, suicidal ideation ( $26.9 \%$ vs $9.2 \%)$ and attempts (19.7\% vs 2.7) (Nock et al., 2008; Spottswood, Davydow, \& Huang, 2017). Although a quantitative analysis was not possible for anxiety due to diversity of anxiety-related diagnoses, results from the included studies ranged from 8\% to 61.4\% (Devóglio, Corrente, Borgato, \& Godoy, 2017; laisuklang \& Ali, 2017).

As part of our subgroup analyses, we observed higher proportions of PTSD among street-based sex workers when compared to other setting (bars, venues, hotels. etc). This phenomenon could be explained due to lack of access to health services, work-related stigma, illegal status, and more importantly exposure to higher rates of workplace violence among FSW working in these settings; however, several other factors could also be associated into this observation. Another interesting finding in our subgroup analysis was also related to PTSD, where we observed higher rates of it among studies that were performed in countries where sex work is partially legal compared to completely legal $(61.9 \%$ vs $12.9 \%, p<\cdot 001)$. FSW who work in countries where sex work is not legal may be more prone to being exposed to different types of violence, social and cultural stigma, as well as lack of access to health services (Romans et al., 2001; Rössler et al., 2010; H. L. Surratt \& Kurtz, 2012).

The proportion of violence in every study included in this review was above the general proportion of violence against women established by the WHO (World Health Organization, 2020). Violence endured by FSW is constant and prolonged as it occurs in an everyday setting (home, work, public spaces, etc).

Perpetrators are usually family members, friends, strangers, intimate partners, clients, peers and even health care workers. Although not generalizable for the entire FSW population, this is a major distinction from other traumatic environments which could elevate rates of PTSD among them (Evens et al., 2019).

Among the included studies, there was a highly consistent presence of perpetuating interpersonal trauma among FSW, including sexual abuse and physical assault. Most studies reported a history of childhood physical, emotional, psychological, and sexual violence, where there also was a significant correlation between these variables and a current diagnosis of PTSD. The proportion of affected individuals was reported to be as high as $82 \%$ in some cohorts. Hence, in 
addition to current work and domestic violence, history of complex childhood trauma as frequently observed among the studies in this systematic review may be another heavy contributing factor to the pooled prevalence for PTSD and other stress-related symptoms in our meta-analysis, in which interpersonal trauma plays a more critical role compared to non-interpersonal and context trauma. The previous hypothesis being supported from findings in several studies involving participants with a history of exposure to childhood violence, neglect, and sexual abuse (Roxburgh. Degenhardt \& Copeland, 2006; Coetzee et al. 2018; Dorahy et al. 2009).

The predicament of FSW in these different countries is not the same; most are victims of gender-based violence, but possibilities of protection vary considerably between countries. The same holds for stigma and family support.

In the interpretation of our results, it is important to consider that mental health issues for FSW are present across cultures. Sex work is a profession that is practiced worldwide and as evidenced in our review, the included references come from more than 25 countries and 5 continents. The manifestation of mental health in general among this population could vary depending on their country of origin as well as their country of residence and work for the following considerations: legal status regarding the profession, cultural perceptions of sex work and mental illness or psychological symptoms, access to physical and mental health services as well as to legal services, country economic status, among others. Adverse circumstances regarding some of the previously mentioned could negatively affect the working environment surrounding sex work and directly elevate rates of stigmatization, gender based and workplace violence among them. Also, noting that cultural factors could influence and affect the reporting of mental health problems should also be considered in the design of much needed implementation strategies to promote mental health treatment among this vulnerable population. These strategies should be individualized based on each country and culture due to some of the previously mentioned aspects.

Another significant issue is the high HIV prevalence among FSW (Paz-Bailey, Noble, Salo, \& Tregear, 2016). Evidence suggests a relation between poor mental health and HIV-risk behaviors such as unprotected vaginal or oral sex, IV drug use, sex under the influence of alcohol or drugs, and syringe exchange, etc (Grosso et al., 2019; Lau et al., 2010; Rogers, Lemstra, \& Moraros, 2015; Sagtani et al., 2013; Shen \& Zou, 2016; Ulibarri et al., 2013). Depression, for example, may increase HIV-risk behaviors due to several factors such as impairment in cognitive function, decreased impulse control, reduced motivation, and increased fatalism. Moreover, following Beck's theory of depression, negative thoughts and feelings surround how depressed people perceive themselves and could ultimately influence their behavior and prevent them from making rational decisions, which will often be based on emotions (Khan et al., 2009; Seth et al., 2011). Regarding PTSD, two main mechanisms have been described to be involved in the process of impulsive and risky behaviors. The first one is an impairment in emotion regulation, a multi-component construct composed by lack of acceptance, difficulties in engaging in goal-directed behaviors when distressed, difficulty in impulse control, limited access to effective emotion regulation strategies, lack of emotional awareness and clarity. The second one is impulsivity, as it is a well-established correlate of risky behaviors such as the addressed in our review (Strom et al., 2012; Tull et al., 2014).

Understanding the complex relation between the abovementioned is substantial for promoting health policies and effective interventions for HIV-prevention and mental health treatment on this population. Behavioral, social, and community-empowerment interventions have shown promising results on reducing rates of risk behaviors and even the incidence of HIV and other sexually transmitted diseases. These interventions should be considered in the process of developing future health policies for vulnerable populations such as FSW (Chow et al., 2015; Kerrigan, Fonner, Stromdahl, \& Kennedy, 2013).

Strengths from this review include a systematic approach to identify and synthesize all available evidence from the most frequent and debilitating mental disorders worldwide, with over 8,000 screened references (Gu et al., 2010; Hilary L Surratt et al., 2005; Wang et al., 2007). Moreover, we only included studies whose outcomes were evaluated with a validated scale which provides more validity to our results. Although we presented the general pooled prevalence for each outcome, subgroup analyses were also provided for self-reported and rater-administered instruments, sex work legal status based by country, work setting, sample size and methods, study quality and time presentation for suicidal behavior. This stratification allows for a more comprehensive analysis on the implications for each outcome and for finding sources of heterogeneity. We also decided to implement a Generalized Linear Mixed Method for metaanalysis due to evidence indicating misleading results from the back-transformation to the original prevalence when using the inverse of the Freeman-Tukey double arcsine transformation (Schwarzer \& Chemaitelly, 2019).

The present review is subject to some limitations. The most important one is that when evaluating study quality, we identified that studies consistently did not justify sample size or report non-response rate and the characteristics of non-responders. Moreover, nearly a third of the included studies employed inadequate sampling methods and study quality could be a source of bias in our results. As FSW comprise a heterogeneous and hard-to-reach population, this potentially leads to selection bias and non-representativeness, consequently affecting the interpretation of the results. Additionally, we acknowledge that the results may not fully reflect the real prevalence and rather represent pooled proportions from observational studies. Another important consideration is that the real prevalence may be overestimated since most measures were obtained through screening instruments. Also, although we carefully evaluated each article for this issue, we acknowledge that participant repetition could be present as some studies might have been performed using the same population cohorts; however, by summing up participants only by outcome instead of overall, the probability of this scenario being present was diminished. We consider that these matters do not hinder the observed results as they highlight the alarmingly high occurrence of psychiatric morbidity in FSW, most probably related to violence exposure, comorbidities, and the multidimensional barriers they face.

An important topic to address is the consistently high heterogeneity throughout the analysis. Although our subgroup and sensitivity analysis did not provide sufficient explanations, the unexplained heterogeneity could be the result of three main factors. Firstly, FSW have a great diversity of social, working, economic, political, and more importantly, cultural circumstances. Moreover, stigma associated with sex work itself also varies across settings and countries, as has been previously reported (Sawicki et al., 2019). As a result, some FSW could be at greater risk of mental health problems compared to others. Secondly, clinimetrics employed to measure outcomes varied considerably across studies. Although evidence suggests strong positive correlations between many of them, we still consider this a source of heterogeneity (Smarr \& Keefer, 2011; Titov et al., 2011). Finally, the observational nature of the studies is another 
potential source. However, it is highly expected to observe high heterogeneity in prevalence meta-analyses, and this topic should be addressed in future research on meta-analytical methods.

As a conclusion, high prevalence of depression, PTSD, suicidal ideation, and attempt was observed among FSW. Although results could be overestimated due to usage of screening scales, prevalence is still higher when compared to other literature. Understanding the critical impact of poor mental health on this population, its triggers as well as its relationship with HIV-risk behaviors is crucial in the design of new strategies that promote access to physical and mental health services for them. There is an urgent need for FSW to be empowered and demand adequate health access as well as to enforce their human rights and be provided with not only the former but also with decent living conditions and important factors such as workplace protection and access to legal help to prevent the onset of the studied conditions. In the process diminishing risk factors for HIV-risk behaviors while promoting human and decent life and work conditions for this population. Government agencies and institutions should prioritize this as a global health problem.

\section{Declarations}

\section{Funding}

The present study did not receive any grants or funding from an independent organization or sector, neither public, commercial, nor non-profit.

\section{$\underline{\text { Conflicts of Interest }}$}

The authors do not have any conflicts of interest to state.

Ethics Approval

Not applicable

\section{Consent to participate}

Not applicable

Consent for publication

All authors have reviewed the final version of this manuscript and authorize its submission \& publication.

\section{Availability of Data and Material}

Data used in the present study will be made available upon request to the corresponding author.

$\underline{\text { Code Availability }}$

Not applicable.

Acknowledgements

The authors would like to acknowledge the support of the research staff of the Department of Psychiatry from the Hospital Universitario "Dr. José Eleuterio González" and KER Unit Mexico from the Faculty of Medicine of the Universidad Autónoma de Nuevo León (UANL) during the development of this study.

\section{Author Contributions}

Dr. Millán contributed to the conceptualization, data curation, statistical analysis, methodology, administration, validation \& supervision of the study. Dr. Carranza contributed to the data curation, methodology, administration, supervision \& validation of the study. Dr. de León contributed to the data curation, methodology \& supervision of the study. Dr. Leyva contributed to the methodology, administration, provided software and resources \& validation in the present study. Dr. Guerrero contributed to the methodology, administration, supervision \& validation of the present study. Dr. Barrera contributed to the data curation process, statistical analysis, methodology, provided resources and software for this study. Ms. Garza contributed to the methodology \& provided resources and software for the present study. Dr. Saucedo contributed to the conceptualization, methodology, administration, provided resources, validation \& supervision of the present study. All authors participated in the drafting process of the manuscript and have reviewed and approved its final version for submission \& publication.

\section{References}

Abelson, A., Lyons, C., Decker, M., Ketende, S., Mfochive Njindam, I., Fouda, G., . . Baral, S. D. (2019). Lifetime experiences of gender-based violence, depression and condom use among female sex workers in Cameroon. Int J Soc Psychiatry, 65(6), 445-457. doi: 10.1177/0020764019858646

Alegría, M., Vera, M., Freeman, D. H., Jr., Robles, R., Santos, M. C., \& Rivera, C. L. (1994). HIV infection, risk behaviors, and depressive symptoms among Puerto Rican sex workers. Am J Public Health, 84(12), 2000-2002. doi: 10.2105/ajph.84.12.2000

Berger, B. O., Grosso, A., Adams, D., Ketende, S., Sithole, B., Mabuza, X. S., . . Baral, S. (2018). The Prevalence and Correlates of Physical and Sexual Violence Affecting Female Sex Workers in Swaziland. J Interpers Violence, 33(17), 2745-2766. doi: 10.1177/0886260516629385 
Burnette, M. L., Lucas, E., Ilgen, M., Frayne, S. M., Mayo, J., \& Weitlauf, J. C. (2008). Prevalence and health correlates of prostitution among patients entering treatment for substance use disorders. Arch Gen Psychiatry, 65(3), 337-344. doi: 10.1001/archpsyc.65.3.337

Cange, C. W., Wirtz, A. L., Ky-Zerbo, O., Lougue, M., Kouanda, S., \& Baral, S. (2019). Effects of traumatic events on sex workers' mental health and suicide intentions in Burkina Faso: a trauma-informed approach. Sex Health, 16(4), 348-357. doi: 10.1071/sh17213

Coetzee, J., Buckley, J., Otwombe, K., Milovanovic, M., Gray, G. E., \& Jewkes, R. (2018). Depression and Post Traumatic Stress amongst female sex workers in Soweto, South Africa: A cross sectional, respondent driven sample. PLoS One, 13(7), e0196759. doi: 10.1371/journal.pone.0196759

Cwikel, J., Chudakov, B., Paikin, M., Agmon, K., \& Belmaker, R. H. (2004). Trafficked female sex workers awaiting deportation: comparison with brothel workers. Arch Womens Ment Health, 7(4), 243-249. doi: 10.1007/s00737-004-0062-8

Cwikel, J., Ilan, K., \& Chudakov, B. (2003). Women brothel workers and occupational health risks. J Epidemiol Community Health, 57(10), 809-815. doi: 10.1136/jech.57.10.809

Chen, H., Li, X., Li, B., \& Huang, A. (2017). Negative trust and depression among female sex workers in Western China: The mediating role of thwarted belongingness. Psychiatry Res, 256, 448-452. doi: 10.1016/j.psychres.2017.06.031

Chow, E. P., Tung, K., Tucker, J. D., Muessig, K. E., Su, S., Zhang, X., . . Zhang, L. (2015). Behavioral Interventions Improve Condom Use and HIV Testing Uptake Among Female Sex Workers in China: A Systematic Review and Meta-Analysis. AIDS Patient Care STDS, 29(8), 454-460. doi: 10.1089/apc.2015.0043

Daalder, A. L., Bogaerts, S., \& Bijleveld, C. C. (2013). The severity of childhood abuse and neglect in relationship to post-traumatic stress disorder among female sex workers in the Netherlands. Journal of Aggression, Maltreatment \& Trauma, 22(9), 935-949.

Deering, K. N., Amin, A., Shoveller, J., Nesbitt, A., Garcia-Moreno, C., Duff, P., . . Shannon, K. (2014). A systematic review of the correlates of violence against sex workers. Am J Public Health, 104(5), e42-e54.

Devóglio, L. L., Corrente, J. E., Borgato, M. H., \& Godoy, I. (2017). Smoking among female sex workers: prevalence and associated variables. J Bras Pneumol, 43(1), 6-13. doi: 10.1590/s1806-37562016000000162

Dorahy MJ., Corry M., Shannon M., MacSherry A., Hamliton G., McRobert G., Elder R \& Hanna D. (2009). Complex PTSD, interpersonal trauma and relational consequences: Findings from a treatment-receiving Northern Irish sample. Journal of Affective Disorders , 112(1-3), 71-80. Doi: 10.1016/j.jad.2008.04.003

Downes, M. J., Brennan, M. L., Williams, H. C., \& Dean, R. S. (2016). Development of a critical appraisal tool to assess the quality of cross-sectional studies (AXIS). BMJ Open, 6(12), e011458. doi: 10.1136/bmjopen-2016-011458

Eller, L. S., \& Mahat, G. (2003). Psychological factors in Nepali former commercial sex workers with HIV. J Nurs Scholarsh, 35(1), 53-60. doi: 10.1111/j.15475069.2003.00053.x

Evens, E., Lanham, M., Santi, K., Cooke, J., Ridgeway, K., Morales, G., .. . Desrosiers, P. C. (2019). Experiences of gender-based violence among female sex workers, men who have sex with men, and transgender women in Latin America and the Caribbean: a qualitative study to inform HIV programming. BMC international health and human rights, 19(1), 9 .

Fang, Lin, Deng-Min Chuang, y Maria Al-Raes. «Social Support, Mental Health Needs, and HIV Risk Behaviors: A Gender-Specific, Correlation Study». BMC Public Health 19, n. ${ }^{\circ} 1$ (2019): 651. https://doi.org/10.1186/s12889-019-6985-9.

Farley, M., Lynne, J., \& Cotton, A. J. (2005). Prostitution in Vancouver: violence and the colonization of First Nations women. Transcult Psychiatry, 42(2), 242271. doi: $10.1177 / 1363461505052667$

Ghose, T., Chowdhury, A., Solomon, P., \& Ali, S. (2015). Depression and anxiety among HIV-positive sex workers in Kolkata, India: Testing and modifying the Hospital Anxiety Depression Scale. International Social Work, 58(2), 211-222.

Gilchrist, G., Gruer, L., \& Atkinson, J. (2005). Comparison of drug use and psychiatric morbidity between prostitute and non-prostitute female drug users in Glasgow, Scotland. Addict Behav, 30(5), 1019-1023. doi: 10.1016/j.addbeh.2004.09.003

González-Forteza, C., Rodríguez, E. M., de Iturbe, P. F., Vega, L., \& Tapia, A. J. (2014). Correlatos psicosociales de depresión y riesgo de suicidio en trabajadoras sexuales del Estado de Hidalgo, México. Salud mental, 37(4), 349-354.

Grosso, A. L., Ketende, S. C., Stahlman, S., Ky-Zerbo, O., Ouedraogo, H. G., Kouanda, S., . . Baral, S. D. (2019). Development and reliability of metrics to characterize types and sources of stigma among men who have sex with men and female sex workers in Togo and Burkina Faso. BMC Infect Dis, 19(1), 208. doi: 10.1186/s12879-019-3693-0

Gu, J., Lau, J. T., Chen, H., Chen, X., Liu, C., \& Liu, J. (2010). Mental health and interpersonal factors associated with HIV-related risk behaviors among noninstitutionalized female injection drug users who are also sex workers in China. Women Health, 50(1), 20-36. doi: 10.1080/03630241003601137

Gu, J., Lau, J. T., Li, M., Li, H., Gao, Q., Feng, X., . . Hao, Y. (2014). Socio-ecological factors associated with depression, suicidal ideation and suicidal attempt among female injection drug users who are sex workers in China. Drug Alcohol Depend, 144, 102-110. doi: 10.1016/j.drugalcdep.2014.08.011

Page $7 / 16$ 
Gunn, J. K., Roth, A. M., Center, K. E., \& Wiehe, S. E. (2016). The Unanticipated Benefits of Behavioral Assessments and Interviews on Anxiety, Self-Esteem and Depression Among Women Engaging in Transactional Sex. Community Ment Health J, 52(8), 1064-1069. doi: 10.1007/s10597-015-9844-x

Hengartner, M. P., Islam, M. N., Haker, H., \& Rössler, W. (2015). Mental Health and Functioning of Female Sex Workers in Chittagong, Bangladesh. Front Psychiatry, 6, 176. doi: 10.3389/fpsyt.2015.00176

Hong, Y., Fang, X., Li, X., Liu, Y., Li, M., \& Tai-Seale, T. (2010). Self-perceived stigma, depressive symptoms, and suicidal behaviors among female sex workers in China. J Transcult Nurs, 21(1), 29-34. doi: 10.1177/1043659609349063

Hong, Y., Li, X., Fang, X., \& Zhao, R. (2007a). Correlates of suicidal ideation and attempt among female sex workers in China. Health Care Women Int, 28(5), 490-505. doi: 10.1080/07399330701226529

Hong, Y., Li, X., Fang, X., \& Zhao, R. (2007b). Depressive symptoms and condom use with clients among female sex workers in China. Sex Health, 4(2), 99-104. doi: $10.1071 / \mathrm{sh} 06063$

laisuklang, M. G., \& Ali, A. (2017). Psychiatric morbidity among female commercial sex workers. Indian J Psychiatry, 59(4), 465-470. doi: 10.4103/psychiatry.IndianJPsychiatry_147_16

Jung, M. (2012). Sexual, behavioral, and social characteristics of female sex workers and their risk of sexually transmitted infections: in South Korea. Sexuality and Disability, 30(4), 421-431.

Kerrigan, D. L., Fonner, V. A., Stromdahl, S., \& Kennedy, C. E. (2013). Community empowerment among female sex workers is an effective HIV prevention intervention: a systematic review of the peer-reviewed evidence from low- and middle-income countries. AIDS Behav, 17(6), 1926-1940. doi: 10.1007/s10461013-0458-4

Kessler, R. C., Aguilar-Gaxiola, S., Alonso, J., Benjet, C., Bromet, E. J., Cardoso, G., . . Ferry, F. (2017). Trauma and PTSD in the WHO world mental health surveys. Eur J Psychotraumatol, 8(sup5), 1353383.

Khan, M. R., Kaufman, J. S., Pence, B. W., Gaynes, B. N., Adimora, A. A., Weir, S. S., \& Miller, W. C. (2009). Depression, sexually transmitted infection, and sexual risk behavior among young adults in the United States. Archives of Pediatrics and Adolescent Medicine, 163(7), 644-652.

https://doi.org/10.1001/archpediatrics.2009.95

Lau, J. T., Tsui, H. Y., Ho, S. P., Wong, E., \& Yang, X. (2010). Prevalence of psychological problems and relationships with condom use and HIV prevention behaviors among Chinese female sex workers in Hong Kong. AIDS Care, 22(6), 659-668. doi: 10.1080/09540120903431314

Lim, G. Y., Tam, W. W., Lu, Y., Ho, C. S., Zhang, M. W., \& Ho, R. C. (2018). Prevalence of depression in the community from 30 countries between 1994 and 2014. Scientific reports, 8(1), 1-10.

Ling, D. C., Wong, W. C., Holroyd, E. A., \& Gray, S. A. (2007). Silent killers of the night: an exploration of psychological health and suicidality among female street sex workers. J Sex Marital Ther, 33(4), 281-299. doi: 10.1080/00926230701385498

MacLean, S. A., Lancaster, K. E., Lungu, T., Mmodzi, P., Hosseinipour, M. C., Pence, B. W., ... Miller, W. C. (2018). Prevalence and correlates of probable depression and post-traumatic stress disorder among female sex workers in Lilongwe, Malawi. Int J Ment Health Addict, 16(1), 150-163. doi: 10.1007/s11469017-9829-9

Morina, N., Stam, K., Pollet, T. V., \& Priebe, S. (2018). Prevalence of depression and posttraumatic stress disorder in adult civilian survivors of war who stay in war-afflicted regions. A systematic review and meta-analysis of epidemiological studies. Journal of Affective Disorders, 239, $328-338$.

Nock, M. K., Borges, G., Bromet, E. J., Alonso, J., Angermeyer, M., Beautrais, A., . . Gluzman, S. (2008). Cross-national prevalence and risk factors for suicidal ideation, plans and attempts. The British Journal of Psychiatry, 192(2), 98-105.

Ortblad, K. F., Musoke, D. K., Chanda, M. M., Ngabirano, T., Velloza, J., Haberer, J. E., . . Bärnighausen, T. (2020). Knowledge of HIV Status Is Associated With a Decrease in the Severity of Depressive Symptoms Among Female Sex Workers in Uganda and Zambia. J Acquir Immune Defic Syndr, 83(1), 37-46. doi: $10.1097 /$ qai.0000000000002224

Pandiyan, K., Chandrasekhar, H., \& Madhusudhan, S. (2012). Psychological morbidity among female commercial sex workers with alcohol and drug abuse. Indian J Psychiatry, 54(4), 349-351. doi: 10.4103/0019-5545.104822

Park, J. N., \& Decker, M. R. (2019). Cumulative Violence and PTSD Symptom Severity Among Urban Street-Based Female Sex Workers. 886260519884694. doi: $10.1177 / 0886260519884694$

Patel, S. K., Ganju, D., Prabhakar, P., \& Adhikary, R. (2016). Relationship between mobility, violence and major depression among female sex workers: a crosssectional study in southern India. BMJ Open, 6(9), e011439. doi: 10.1136/bmjopen-2016-011439

Patel, S. K., Saggurti, N., Pachauri, S., \& Prabhakar, P. (2015). Correlates of Mental Depression Among Female Sex Workers in Southern India. Asia Pac J Public Health, 27(8), 809-819. doi: 10.1177/1010539515601480 
Patel, Vikram, Dan Chisholm, Rachana Parikh, Fiona J Charlson, Louisa Degenhardt, Tarun Dua, Alize J Ferrari, et al. «Addressing the Burden of Mental, Neurological, and Substance Use Disorders: Key Messages from Disease Control Priorities, 3rd Edition». The Lancet 387, n. ${ }^{\circ} 10028$ (abril de 2016 ): $1672-85$. https://doi.org/10.1016/S0140-6736(15)00390-6.

Paz-Bailey, G., Noble, M., Salo, K., \& Tregear, S. J. (2016). Prevalence of HIV Among U.S. Female Sex Workers: Systematic Review and Meta-analysis. AIDS Behav, 20(10), 2318-2331. doi: 10.1007/s10461-016-1332-y

Poliah, V., \& Paruk, S. (2017). Depression, anxiety symptoms and substance use amongst sex workers attending a non-governmental organisation in KwaZuluNatal, South Africa. South African Family Practice, 59(3), 116-122.

ProCon.org. (2018). Countries and Their Prostitution Policies.

Rael, C. T., \& Davis, A. (2017). Depression and key associated factors in female sex workers and women living with HIV/AIDS in the Dominican Republic. Int J STD AIDS, 28(5), 433-440. doi: 10.1177/0956462416651374

Ranjbar, F., Sadeghi-Bazargani, H., Pishgahi, A., Nobari, O., Farahbakhsh, M., Farhang, S., .. Dareshiri, S. (2019). Mental health status among female sex workers in Tabriz, Iran. Arch Womens Ment Health, 22(3), 391-397. doi: 10.1007/s00737-018-0907-1

Roberts, S. T., Flaherty, B. P., Deya, R., Masese, L., Ngina, J., McClelland, R. S., . . Graham, S. M. (2018). Patterns of Gender-Based Violence and Associations with Mental Health and HIV Risk Behavior Among Female Sex Workers in Mombasa, Kenya: A Latent Class Analysis. AIDS Behav, 22(10), 3273-3286. doi: $10.1007 /$ s10461-018-2107-4

Rogers, M. R., Lemstra, M. E., \& Moraros, J. S. (2015). Risk Indicators of Depressed Mood Among Sex-Trade Workers and Implications for HIV Risk Behaviour. Can J Psychiatry, 60(12), 548-555. doi: 10.1177/070674371506001205

Romans, S. E., Potter, K., Martin, J., \& Herbison, P. (2001). The mental and physical health of female sex workers: a comparative study. Australian \& New Zealand Journal of Psychiatry, 35(1), 75-80.

Rössler, W., Koch, U., Lauber, C., Hass, A. K., Altwegg, M., Ajdacic-Gross, V., \& Landolt, K. (2010). The mental health of female sex workers. Acta psychiatrica scandinavica, 122(2), 143-152.

Roxburgh, A., Degenhardt, L., \& Copeland, J. (2006). Posttraumatic stress disorder among female street-based sex workers in the greater Sydney area, Australia. BMC Psychiatry, 6, 24. doi: 10.1186/1471-244x-6-24

Sabri, B., Huerta, J., Alexander, K. A., Vil, N. M. S., Campbell, J. C., \& Callwood, G. B. (2015). Multiple intimate partner violence experiences: Knowledge, access, utilization and barriers to utilization of resources by women of the African diaspora. Journal of health care for the poor and underserved, $26(4), 1286$.

Sagtani, R. A., Bhattarai, S., Adhikari, B. R., Baral, D., Yadav, D. K., \& Pokharel, P. K. (2013). Violence, HIV risk behaviour and depression among female sex workers of eastern Nepal. BMJ Open, 3(6). doi: 10.1136/bmjopen-2013-002763

Sawicki, D. A., Meffert, B. N., Read, K., \& Heinz, A. J. (2019). Culturally competent health care for sex workers: an examination of myths that stigmatize sex work and hinder access to care. Sexual and Relationship Therapy, 34(3), 355-371. https://doi.org/10.1080/14681994.2019.1574970

Schwarzer, G., \& Chemaitelly, H. (2019). Seriously misleading results using inverse of Freeman-Tukey double arcsine transformation in meta-analysis of single proportions. 10(3), 476-483. doi: 10.1002/jrsm.1348

Semple, S. J., \& Pines, H. A. (2020). Maternal role strain and depressive symptoms among female sex workers in Mexico: the moderating role of sex work venue. 60 (3), 284-299. doi: 10.1080/03630242.2019.1626792

Seth, P., Patel, S. N., Sales, J. M., Diclemente, R. J., Wingood, G. M., \& Rose, E. S. (2011). The impact of depressive symptomatology on risky sexual behavior and sexual communication among African American female adolescents. Psychology, Health and Medicine, 16(3), 346-356.

https://doi.org/10.1080/13548506.2011.554562

Shahmanesh, M., Wayal, S., Cowan, F., Mabey, D., Copas, A., \& Patel, V. (2009). Suicidal behavior among female sex workers in Goa, India: the silent epidemic. Am J Public Health, 99(7), 1239-1246. doi: 10.2105/ajph.2008.149930

Shen, H., \& Zou, H. (2016). Depression and HIV Risk Behaviors among Female Sex Workers in Guangdong, China: A Multicenter Cross-Sectional Study. 2016, 6986173. doi: 10.1155/2016/6986173

Smarr, K. L., \& Keefer, A. L. (2011). Measures of depression and depressive symptoms: beck depression inventory-II (BDI-II), Center for Epidemiologic Studies Depression Scale (CES-D), geriatric depression scale (GDS), hospital anxiety and depression scale (HADS), and patient health Questionnaire-9 (PHQ-9).

Arthritis care \& research, 63(S11), S454-S466.

Spottswood, M., Davydow, D. S., \& Huang, H. (2017). The prevalence of posttraumatic stress disorder in primary care: a systematic review. Harvard review of psychiatry, 25(4), 159. 
Stijnen, T., Hamza, T. H., \& Ozdemir, P. (2010). Random effects meta-analysis of event outcome in the framework of the generalized linear mixed model with applications in sparse data. Stat Med, 29(29), 3046-3067. doi: 10.1002/sim.4040

Strom, T. Q., Leskela, J., James, L. M., Thuras, P. D., Voller, E., Weigel, R., Yutsis, M., Khaylis, A., Lindberg, J., \& Holz, K. B. (2012). An exploratory examination of risk-taking behavior and PTSD symptom severity in a Veteran sample. Military Medicine, 177(4), 390-396. https://doi.org/10.7205/MILMED-D-11-00133

Stroup, D. F., Berlin, J. A., Morton, S. C., Olkin, I., Williamson, G. D., Rennie, D., . . Thacker, S. B. (2000). Meta-analysis of observational studies in epidemiology: a proposal for reporting. Jama, 283(15), 2008-2012.

Studies loD. Sexuality, Poverty and Law Programme Theme: Sex Work Law Interactions for Gender Justice. Available from: http://spl.ids.ac.uk/sexworklaw/countries.

Štulhofer A, Sinković M, Božić J, Baćak V. Victimization and HIV risks among Croatian female sex workers:exploring the mediation role of depressiveness and the moderation role of social support. Violence Against Women. 2017; 23(1):67-88.

Su, S., Li, X., Zhang, L., Lin, D., Zhang, C., \& Zhou, Y. (2014). Age group differences in HIV risk and mental health problems among female sex workers in Southwest China. AIDS Care, 26(8), 1019-1026.

Suresh, G., Furr, L. A., \& Srikrishnan, A. K. (2009). An assessment of the mental health of street-based sex workers in Chennai, India. Journal of Contemporary Criminal Justice, 25(2), 186-201.

Surratt, H. L., \& Kurtz, S. P. (2012). Foster care history and HIV infection among drug-using African American female sex workers. AIDS Behav, 16(4), 982-989. doi: $10.1007 / \mathrm{s} 10461-011-0008-\mathrm{x}$

Surratt, H. L., Kurtz, S. P., Weaver, J. C., \& Inciardi, J. A. (2005). The connections of mental health problems, violent life experiences, and the social milieu of the "stroll" with the HIV risk behaviors of female street sex workers. Journal of Psychology \& Human Sexuality, 17(1-2), 23-44.

Teixeira, A., \& Oliveira, A. (2017). Exploratory study on the prevalence of suicidal behavior, mental health, and social support in female street sex workers in Porto, Portugal. Health Care Women Int, 38(2), 159-166. doi: 10.1080/07399332.2016.1192172

Titov, N., Dear, B. F., McMillan, D., Anderson, T., Zou, J., \& Sunderland, M. (2011). Psychometric comparison of the PHQ-9 and BDI-II for measuring response during treatment of depression. Cogn Behav Ther, 40(2), 126-136. doi: 10.1080/16506073.2010.550059

Tull, M. T., Weiss, N. H., \& Mcdermott, M. J. (2014). Comprehensive Guide to Post-Traumatic Stress Disorder. Comprehensive Guide to Post-Traumatic Stress Disorder, 1-12. https://doi.org/10.1007/978-3-319-08613-2

Ulibarri, M. D., Hiller, S. P., Lozada, R., Rangel, M. G., Stockman, J. K., Silverman, J. G., \& Ojeda, V. D. (2013). Prevalence and characteristics of abuse experiences and depression symptoms among injection drug-using female sex workers in Mexico. J Environ Public Health, 2013, 631479. doi: 10.1155/2013/631479

United Nations (2020). United Nations: World Drug Report 2020. Available from: https://wdr.unodc.org/wdr2020/index.html

Valera, R. J., Sawyer, R. G., \& Schiraldi, G. R. (2001). Perceived health needs of inner-city street prostitutes: a preliminary study. Am J Health Behav, 25(1), 5059. doi: 10.5993/ajhb.25.1.6

Wang, B., Li, X., Stanton, B., Fang, X., Yang, H., Zhao, R., \& Hong, Y. (2007). Sexual coercion, HIV-related risk, and mental health among female sex workers in China. Health Care Women Int, 28(8), 745-762. doi: 10.1080/07399330701465226

White, D., Wilson, K. S., Masese, L. N., Wanje, G., Jaoko, W., Mandaliya, K., .. McClelland, R. S. (2016). Alcohol Use and Associations With Biological Markers and Self-Reported Indicators of Unprotected Sex in Human Immunodeficiency Virus-Positive Female Sex Workers in Mombasa, Kenya. Sex Transm Dis, 43(10), 642-647. doi: 10.1097/olq.0000000000000502

World Health Organization. (2017). Violence against women. Available from: https://www.who.int/news-room/fact-sheets/detail/violence-against-women WHO (2020). Global and regional estimates of violence against women. Who.int. 2020 Available from: https://www.who.int/reproductivehealth/publications/violence/9789241564625/en/

Witte, S. S., Batsukh, A., \& Chang, M. (2010). Sexual risk behaviors, alcohol abuse, and intimate partner violence among sex workers in Mongolia: implications for HIV prevention intervention development. J Prev Interv Community, 38(2), 89-103. doi: 10.1080/10852351003640625

Yang, H., Li, X., Stanton, B., Chen, X., Liu, H., Fang, X., . . Mao, R. (2005). HIV-related risk factors associated with commercial sex among female migrants in China. Health Care Women Int, 26(2), 134-148.

Yuen, W. W., Tran, L., Wong, C. K., Holroyd, E., Tang, C. S., \& Wong, W. C. (2016). Psychological health and HIV transmission among female sex workers: a systematic review and meta-analysis. AIDS Care, 28(7), 816-824. doi: 10.1080/09540121.2016.1139038

Zehnder, M., Mutschler, J., Rössler, W., Rufer, M., \& Rüsch, N. (2019). Stigma as a Barrier to Mental Health Service Use Among Female Sex Workers in Switzerland. Front Psychiatry, 10, 32. doi: 10.3389/fpsyt.2019.00032

Page $10 / 16$ 
Zhang, C., Li, X., Chen, Y., Hong, Y., Shan, Q., Liu, W., \& Zhou, Y. (2014). Alcohol and other drug use, partner violence, and mental health problems among female sex workers in southwest China. Health Care Women Int, 35(1), 60-73. doi: 10.1080/07399332.2012.757317

\section{Tables}




\begin{tabular}{|c|c|c|c|c|c|c|c|c|c|c|c|c|}
\hline Author, year & Country & Status & $\mathbf{N}$ & Age & Site & $\underset{\%)}{\operatorname{HIV}}(+)(n$, & $\begin{array}{l}\text { Above } \\
\text { mean } \\
\text { drug } \\
\text { use }^{g}\end{array}$ & $\begin{array}{l}\text { Above } \\
\text { mean } \\
\text { exp· to } \\
\text { violence }\end{array}$ & Quality & Depression & Anxiety & PTSD \\
\hline $\begin{array}{l}\text { Abelson et al } \\
\text { (2019) }\end{array}$ & Cameroon & I & 2165 & $\begin{array}{l}30.1(23- \\
36)^{\mathrm{e}}\end{array}$ & NR & $\begin{array}{l}526 / 2158 \\
(24.4)\end{array}$ & Yes & Yes & Moderate & $\begin{array}{l}\text { PHQ-9 } \\
\geq 10\end{array}$ & NR & NR \\
\hline $\begin{array}{l}\text { Alegría et al } \\
\text { (1994) }\end{array}$ & Puerto Rico & I & 127 & $32^{b}$ & Mixed & $35(27 \cdot 5)$ & Yes & NR & Low & $\begin{array}{l}\text { CES-D } 20 \\
\geq 16\end{array}$ & NR & NR \\
\hline $\begin{array}{l}\text { Berger et al } \\
\text { (2018) }\end{array}$ & Swaziland & I & 325 & $\begin{array}{l}26.1 \\
(6.2)^{a}\end{array}$ & Mixed & $\begin{array}{l}222 / 319 \\
(69.6)\end{array}$ & Yes & Yes & Moderate & NR & NR & NR \\
\hline $\begin{array}{l}\text { Burnette et al } \\
\text { (2008) }\end{array}$ & $\begin{array}{l}\text { United } \\
\text { States }\end{array}$ & $\mathrm{PL}$ & 816 & $\begin{array}{l}31.56 \\
(6.0)^{\mathrm{a}}\end{array}$ & NR & $54(6.6)$ & Yes & NR & Moderate & NR & NR & NR \\
\hline $\begin{array}{l}\text { Cange et al } \\
\text { (2019) }\end{array}$ & $\begin{array}{l}\text { Burkina } \\
\text { Faso }\end{array}$ & PL & 696 & $\begin{array}{l}26(18- \\
59)^{\mathrm{C}}\end{array}$ & Mixed & NR & NR & Yes & High & NR & NR & NR \\
\hline $\begin{array}{l}\text { Chen et al } \\
\text { (2017) }\end{array}$ & China & I & 457 & $\begin{array}{l}25.15 \\
(5.9)^{a}\end{array}$ & Mixed & NR & NR & NR & Moderate & $\begin{array}{l}\text { CES-D } 20 \\
\geq 16\end{array}$ & NR & NR \\
\hline $\begin{array}{l}\text { Coetzee et al } \\
(2018)\end{array}$ & $\begin{array}{l}\text { South } \\
\text { Africa }\end{array}$ & I & 508 & $\begin{array}{l}31(25- \\
37)^{c}\end{array}$ & NR & NR & NR & Yes & High & $\begin{array}{l}\text { CES-D } 20 \\
\geq 21\end{array}$ & NR & $\begin{array}{l}\text { PTSD- } \\
\text { 8/DSM- } \\
\text { IV }\end{array}$ \\
\hline $\begin{array}{l}\text { Cwikel et al } \\
\text { (2003) }\end{array}$ & Israel & $\mathrm{L}$ & 55 & $\begin{array}{l}22.8 \\
(4.4)^{a}\end{array}$ & Brothel & NR & Yes & Yes & Moderate & $\begin{array}{l}\text { CES-D } 20 \\
\geq 16\end{array}$ & NR & $\begin{array}{l}\text { PCL-17 } \\
\geq 51\end{array}$ \\
\hline $\begin{array}{l}\text { Cwikel ey al } \\
(2004)\end{array}$ & Israel & $\mathrm{L}$ & 47 & $\begin{array}{l}22.3 \\
(2.8)^{a}\end{array}$ & NR & NR & NR & Yes & Low & $\begin{array}{l}\text { CES-D } 20 \\
\geq 16\end{array}$ & NR & $\begin{array}{l}\text { PCL-17 } \\
\geq 52\end{array}$ \\
\hline $\begin{array}{l}\text { Daalder et al } \\
\text { (2013) }\end{array}$ & Netherlands & $\mathrm{L}$ & 123 & $\begin{array}{l}33.5(9.2) \\
a\end{array}$ & Mixed & NR & NR & Yes & Moderate & NR & NR & $\begin{array}{l}\text { SRIP } \\
\geq 53\end{array}$ \\
\hline $\begin{array}{l}\text { Devoglio et } \\
\text { al (2017) }\end{array}$ & Brazil & $\mathrm{L}$ & 83 & $\begin{array}{l}26.8 \\
(6.3)^{a}\end{array}$ & NR & NR & Yes & NR & Moderate & HADS & HADS & NR \\
\hline $\begin{array}{l}\text { Eller et al } \\
(2003)\end{array}$ & Nepal & I & 98 & $\begin{array}{l}20.2(13- \\
39)^{f}\end{array}$ & NR & $98(100)$ & NR & NR & Moderate & $\begin{array}{l}\text { CES-D } 20 \\
\geq 16\end{array}$ & $\begin{array}{l}\text { SCL- } \\
\text { AS }\end{array}$ & NR \\
\hline $\begin{array}{l}\text { Farley et al } \\
\text { (2005) }\end{array}$ & Canada & PL & 100 & $\begin{array}{l}28(13- \\
49)^{f}\end{array}$ & Mixed & NR & NR & Yes & Moderate & NR & NR & DSM-IV \\
\hline $\begin{array}{l}\text { Ghose et al } \\
\text { (2013) }\end{array}$ & India & $\mathrm{L}$ & 100 & $23^{b}$ & Mixed & $100(100)$ & NR & NR & Moderate & HADS & HADS & NR \\
\hline $\begin{array}{l}\text { Gilchrist et al } \\
\text { (2005) }\end{array}$ & Scotland & $\mathrm{L}$ & 176 & NR & NR & NR & Yes & Yes & Low & CIS-R $\geq 18$ & $\begin{array}{l}\text { CIS-R } \\
\geq 18\end{array}$ & NR \\
\hline $\begin{array}{l}\text { González- } \\
\text { Forteza } \\
\text { (2014) }\end{array}$ & Mexico & $\mathrm{L}$ & 103 & $\begin{array}{l}28(6.7) \\
a\end{array}$ & Mixed & NR & NR & NR & Low & MINI & NR & NR \\
\hline $\begin{array}{l}\text { Grosso et al } \\
(2019)\end{array}$ & $\begin{array}{l}\text { Burkina } \\
\text { Faso \& } \\
\text { Togo }\end{array}$ & $\mathrm{PL}$ & 1383 & NR & NR & NR & NR & NR & Low & NR & NR & NR \\
\hline $\begin{array}{l}\text { Gu et al } \\
(2014)\end{array}$ & China & I & 200 & $\begin{array}{l}33.9 \\
(5.3)^{a}\end{array}$ & Mixed & NR & NR & NR & Moderate & $\begin{array}{l}\text { CDAS-DS } \\
\geq 14\end{array}$ & NR & NR \\
\hline $\begin{array}{l}\text { Gunn et al } \\
\text { (2015) }\end{array}$ & $\begin{array}{l}\text { United } \\
\text { States }\end{array}$ & $\mathrm{PL}$ & 24 & $42.5^{d}$ & Mixed & NR & Yes & NR & Moderate & NR & BSI-A & NR \\
\hline $\begin{array}{l}\text { Hengartner } \\
\text { et al (2015) }\end{array}$ & Bangladesh & $\mathrm{L}$ & 259 & $\begin{array}{l}23.2 \\
(6.7)^{a}\end{array}$ & Mixed & NR & Yes & Yes & High & MH-CIDI & $\begin{array}{l}\mathrm{MH}- \\
\mathrm{CIDI}\end{array}$ & $\begin{array}{l}\mathrm{MH}- \\
\mathrm{CIDI}\end{array}$ \\
\hline $\begin{array}{l}\text { Hong et al } \\
\text { (2007) }\end{array}$ & China & I & 454 & $\begin{array}{l}23.5 \\
(5.1)^{\mathrm{a}}\end{array}$ & Mixed & NR & NR & NR & Moderate & NR & NR & NR \\
\hline $\begin{array}{l}\text { Hong et al } \\
\text { (2007) }\end{array}$ & China & I & 278 & $\begin{array}{l}23.5 \\
(5.1)^{\mathrm{a}}\end{array}$ & NR & NR & NR & NR & Moderate & CES-D $\geq 16$ & NR & NR \\
\hline $\begin{array}{l}\text { Hong et al } \\
(2010)\end{array}$ & China & I & 310 & $\begin{array}{l}22.5 \\
(3.9)^{a}\end{array}$ & Mixed & NR & NR & NR & Moderate & CES-D $\geq 16$ & NR & NR \\
\hline $\begin{array}{l}\text { Hong et al } \\
\text { (2013) }\end{array}$ & China & I & 1022 & $\begin{array}{l}24.9 \\
(6.7)^{\mathrm{a}}\end{array}$ & Mixed & NR & Yes & Yes & Moderate & CES-D $\geq 16$ & NR & NR \\
\hline laisuklang et & India & $\mathrm{L}$ & 100 & 29.5 & Mixed & $\begin{array}{l}\text { NR } \\
\text { age } 12 / 16\end{array}$ & Yes & Yes & Low & MINI & MINI & MINI \\
\hline
\end{tabular}




\begin{tabular}{|c|c|c|c|c|c|c|c|c|c|c|c|c|}
\hline al (2017) & & & & $(6.9)^{a}$ & & & & & & & & \\
\hline $\begin{array}{l}\text { Jung et al } \\
\text { (2012) }\end{array}$ & $\begin{array}{l}\text { South } \\
\text { Korea }\end{array}$ & IL & 1073 & $\begin{array}{l}28.7 \\
(5.8)^{a}\end{array}$ & Brothel & NR & NR & NR & High & NR & NR & NR \\
\hline $\begin{array}{l}\text { Lau et al } \\
(2010)\end{array}$ & $\begin{array}{l}\text { China } \\
\text { (Hong } \\
\text { Kong) }\end{array}$ & I & 293 & NR & Mixed & NR & Yes & NR & High & CES-D $\geq 16$ & NR & NR \\
\hline $\begin{array}{l}\text { Ling et al } \\
\text { (2007) }\end{array}$ & China & I & 89 & $36^{b}$ & Streets & NR & NR & NR & Moderate & NR & NR & NR \\
\hline $\begin{array}{l}\text { MacLean et } \\
\text { al (2018) }\end{array}$ & Malawi & L & 200 & $\begin{array}{l}24(22- \\
28)^{c}\end{array}$ & Mixed & 138 (69) & NR & NR & High & $\begin{array}{l}\text { PHQ-9 } \\
\geq 10\end{array}$ & NR & PCL-C \\
\hline $\begin{array}{l}\text { Ortblad et al } \\
(2020)^{g}\end{array}$ & $\begin{array}{l}\text { Uganda \& } \\
\text { Zambia }\end{array}$ & I & 1925 & $\begin{array}{l}26.6 \\
(6.5)^{a}\end{array}$ & Mixed & NR & NR & NR & Moderate & $\begin{array}{l}\text { PHQ-9 } \\
\geq 10\end{array}$ & NR & NR \\
\hline $\begin{array}{l}\text { Pandiyan et } \\
\text { al (2012) }\end{array}$ & India & L & 100 & $\begin{array}{l}31.7 \\
(7 \cdot 9)^{a}\end{array}$ & NR & $2(2)$ & Yes & NR & Low & $\mathrm{GHQ}$ & $\mathrm{GHQ}$ & NR \\
\hline $\begin{array}{l}\text { Park et al } \\
\text { (2019) }\end{array}$ & $\begin{array}{l}\text { United } \\
\text { States }\end{array}$ & $\mathrm{PL}$ & 220 & $\begin{array}{l}35.7 \\
(8.9)^{a}\end{array}$ & Streets & NR & Yes & Yes & Moderate & NR & NR & $\begin{array}{l}\text { PCL-5 } \\
\geq 33\end{array}$ \\
\hline $\begin{array}{l}\text { Patel et al } \\
\text { (2015) }\end{array}$ & India & L & 1986 & $\begin{array}{l}29.2 \\
(5.3)^{a}\end{array}$ & Mixed & NR & NR & NR & High & PHQ-2 $\geq 3$ & NR & NR \\
\hline $\begin{array}{l}\text { Patel et al } \\
\text { (2016) }\end{array}$ & India & L & 2400 & $\begin{array}{l}31(5.8) \\
\mathrm{a}\end{array}$ & Mixed & NR & NR & NR & High & PHQ-2 $\geq 3$ & NR & NR \\
\hline $\begin{array}{l}\text { Poliah et al } \\
\text { (2017) }\end{array}$ & $\begin{array}{l}\text { South } \\
\text { Africa }\end{array}$ & IL & 150 & NR & NR & NR & NR & Yes & Moderate & PHQ-9 $\geq 5$ & NR & NR \\
\hline $\begin{array}{l}\text { Rael et al } \\
\text { (2017) }\end{array}$ & $\begin{array}{l}\text { Dominican } \\
\text { Republic }\end{array}$ & L & 349 & $\begin{array}{l}27.5 \\
(6.7)^{a}\end{array}$ & Mixed & NR & NR & NR & Moderate & $\begin{array}{l}\text { CES-D } 10 \\
\geq 10\end{array}$ & NR & NR \\
\hline $\begin{array}{l}\text { Ranjbar et al } \\
(2019)\end{array}$ & Iran & I & 48 & $30.9^{b}$ & Streets & NR & NR & Yes & Moderate & SCID & SCID & NR \\
\hline $\begin{array}{l}\text { Roberts et al } \\
\text { (2018) }\end{array}$ & Kenya & L & 283 & $\begin{array}{l}33.5 \\
\left(27.2^{-}\right. \\
40.6)^{c}\end{array}$ & Mixed & NR & $\mathrm{NR}$ & Yes & Moderate & $\begin{array}{l}\text { PHQ-9 } \\
\geq 10\end{array}$ & NR & $\begin{array}{l}\text { PCL-C } \\
\geq 30\end{array}$ \\
\hline $\begin{array}{l}\text { Rogers et al } \\
(2015)\end{array}$ & Canada & $P L$ & 217 & NR & Mixed & NR & NR & NR & Moderate & $\begin{array}{l}\text { CES-D } 20 \\
\geq 16\end{array}$ & NR & NR \\
\hline $\begin{array}{l}\text { Rossler et al } \\
\text { (2010) }\end{array}$ & Switzerland & L & 193 & $\begin{array}{l}32.1(18- \\
63)^{f}\end{array}$ & Mixed & NR & NR & Yes & Moderate & $\begin{array}{l}\text { MH-CIDI } \\
2 \cdot 1\end{array}$ & $\begin{array}{l}\mathrm{MH}- \\
\mathrm{CIDI} \\
2 \cdot 1\end{array}$ & $\begin{array}{l}\mathrm{MH}- \\
\mathrm{CIDI} 2 \cdot 1\end{array}$ \\
\hline $\begin{array}{l}\text { Roxburgh et } \\
\text { al (2006) }\end{array}$ & Australia & $P L$ & 72 & $\begin{array}{l}34(8.8) \\
\mathrm{a}\end{array}$ & Streets & NR & Yes & Yes & Moderate & $B D I \geq 29$ & NR & CIDI \\
\hline $\begin{array}{l}\text { Sagtani et al } \\
(2013)\end{array}$ & Nepal & I & 210 & NR & NR & NR & NR & Yes & High & $\begin{array}{l}\text { CES-D } 20 \\
\geq 16\end{array}$ & NR & NR \\
\hline $\begin{array}{l}\text { Semple et al } \\
(2020)\end{array}$ & Mexico & L & 426 & $\begin{array}{l}33.8 \\
(8.0)^{a}\end{array}$ & Mixed & NR & NR & NR & High & BDI-II $\geq 20$ & NR & NR \\
\hline $\begin{array}{l}\text { Shahmanesh } \\
\text { et al (2009) }\end{array}$ & India & L & 326 & NR & Mixed & $\begin{array}{l}84 \\
(25.8)^{g}\end{array}$ & Yes & Yes & Moderate & NR & NR & NR \\
\hline $\begin{array}{l}\text { Shen et al } \\
\text { (2016) }\end{array}$ & China & I & 653 & NR & Mixed & $4(0.6)$ & No & NR & Moderate & $\begin{array}{l}\text { GHQ-12 } \\
\geq 6\end{array}$ & NR & NR \\
\hline $\begin{array}{l}\text { Su et al } \\
(2014)\end{array}$ & China & I & 1022 & NR & NR & NR & Yes & NR & Moderate & NR & NR & NR \\
\hline $\begin{array}{l}\text { Surratt et al } \\
(2005)\end{array}$ & $\begin{array}{l}\text { United } \\
\text { States }\end{array}$ & $P L$ & 278 & $35.2^{b}$ & Streets & $\begin{array}{l}52 \\
(18.7)^{g}\end{array}$ & Yes & Yes & Moderate & $\mathrm{BDI}-\mathrm{II} \geq 20$ & BAI & $\mathrm{TSI} \geq 5$ \\
\hline $\begin{array}{l}\text { Surratt et al } \\
(2012)^{\mathrm{h}}\end{array}$ & $\begin{array}{l}\text { United } \\
\text { States }\end{array}$ & $P L$ & 562 & $\begin{array}{l}39.31 \\
(8.5)^{a}\end{array}$ & Streets & $\begin{array}{l}103 \\
(18.3)^{g}\end{array}$ & Yes & Yes & Moderate & GAIN $\geq 6$ & $\begin{array}{l}\text { GAIN } \\
\geq 6\end{array}$ & $\begin{array}{l}\text { GAIN } \\
\geq 5\end{array}$ \\
\hline $\begin{array}{l}\text { Teixeira et al } \\
(2017)\end{array}$ & Portugal & L & 52 & $\begin{array}{l}38.7 \\
(10.3)^{a}\end{array}$ & Streets & NR & Yes & Yes & Low & NR & NR & NR \\
\hline $\begin{array}{l}\text { Ulibarri et al } \\
\text { (2013) }\end{array}$ & Mexico & L & 624 & $\begin{array}{l}33.7 \\
(8.4)^{a}\end{array}$ & Mixed & NR & NR & Yes & High & $\begin{array}{l}\text { CES-D } 10 \\
\geq 10\end{array}$ & NR & NR \\
\hline $\begin{array}{l}\text { Valera et al } \\
(2001)\end{array}$ & $\begin{array}{l}\text { United } \\
\text { States }\end{array}$ & $P L$ & 42 & $\begin{array}{l}29.5 \\
(10.3)^{a}\end{array}$ & Streets & $1(2.4)^{g}$ & Yes & Yes & Low & NR & NR & PCL-17 \\
\hline
\end{tabular}




\begin{tabular}{|c|c|c|c|c|c|c|c|c|c|c|c|c|}
\hline $\begin{array}{l}\text { White et al } \\
\text { (2016) }\end{array}$ & Kenya & $\mathrm{L}$ & 405 & NR & Mixed & $405(100)$ & NR & Yes & Moderate & $\begin{array}{l}\text { PHQ-9 } \\
\geq 10\end{array}$ & NR & NR \\
\hline $\begin{array}{l}\text { Witte et al } \\
(2010)\end{array}$ & Mongolia & I & 48 & $28^{\mathrm{b}}$ & NR & NR & NR & NR & Low & BSI-DS & NR & NR \\
\hline $\begin{array}{l}\text { Yang et al } \\
\text { (2005) }\end{array}$ & China & I & 40 & $\begin{array}{l}23.9 \\
(3.0)^{\mathrm{a}}\end{array}$ & NR & NR & Yes & NR & Moderate & $\begin{array}{l}\text { CES-D } 20 \\
\geq 16\end{array}$ & NR & NR \\
\hline $\begin{array}{l}\text { Zehnder et al } \\
\text { (2019) }\end{array}$ & Switzerland & $\mathrm{L}$ & 60 & $\begin{array}{l}38.4 \\
(11.7)^{a}\end{array}$ & Mixed & NR & NR & NR & Low & MINI & NR & NR \\
\hline
\end{tabular}

a: Mean (standard deviation); b: Only mean reported; c: Median (interquartile range); d: Only median; e: Mean (interquartile range); f: Mean (range); Sex work include streets, bars, brothels, entertainment establishments, karaoke bars, massage parlors, restaurants, barbershops, hair-washing rooms, mini hotels, danc guest houses, saunas, parlours, cabarets, etc; g: Any study that reported any type of drug use independently of its frequency with a proportion over 7.5\% was mean drug use, the cutoff--point of $7 \cdot 5 \%$ was decided due to it being the upper interval of the prevalence of drug use observed in the average population acco Nations Office of Drugs and Crime (UNDOC) 2020 estimates; f: Any study that reported any type of physical or sexual violence independently of its frequency over $35 \%$ was considered as above the mean for violence exposure, cutoff point was decided according to World Health Organization (WHO) statistics on pre against women; g: Article did not report absolute number for given variable and was therefore calculated from the reported proportion; $\mathrm{h}$ : Data was originally groups and was pooled into a general sample by authors

CES-D: Center for Epidemiological Studies Depression Scale; MINI: International Neuropsychiatric Interview; PHQ: Patient Health Questionnaire; GHQ: General BDI: Beck Depression Inventory; GAIN: Global Appraisal Individual Needs; BSI-DS: Brief Symptom Inventory-Depression Subscale; HADS: Hospital Anxiety Der DS: Chinese Depression Anxiety Stress Scale-Depression Subscale; SCID: Structured Clinical Interview DSM IV; CIS-R: Clinical Interview Schedule-Revised; MH Health Composite International Diagnostic Interview; GHQ: General Health Questionnaire; HADS: Hospital Anxiety Depression Scale; SCL-AS: Symptoms Chec Subscale; CIS-R: Clinical Interview Schedule-Revised: BSI-A: Brief Symptom Interview-Anxiety; WHO MH-CIDI: WHO Mental Health Composite International Dia GAIN: The Global Appraisal Individual Needs; MINI: International Neuropsychiatric Interview; SCID DSM-IV: Structured Clinical Interview for DSM-IV; BAl: Beck PTSD-8: Post Traumatic Stress Disorder-8; PCL-17: PTSD Checklist 17 Item scale; SRIP: Self Rating Inventory for PTSD; MH-CIDI: World Health Organization $\mathrm{A}$ Composite International Diagnostic Interview; GAIN: The Global Appraisal Individual Needs; MINI: International Neuropsychiatric Interview; PCL-C: PTSD Chec PCL-5: PTSD Checklist for DSM-V; NHMWB/CIDI: National Mental Health and Wellbeing version of the Composite International Diagnostic Interview; TSI: Trai PCL: PTSD Checklist; LY: Last year; NR: Not Reported

\begin{tabular}{|c|c|c|c|c|}
\hline Author, year & $\mathbf{N}$ & Scale & Cut-off value & Prevalence $(n, \%)$ \\
\hline Pandiyan et al (2012) & 100 & GHQ & NR & $42(42)$ \\
\hline Devoglio et al (2017) & 83 & HADS & NR & $51(61 \cdot 4)$ \\
\hline Eller et al (2003) & 98 & SCL-AS & NR & $4(4)^{a}$ \\
\hline Gilchrist et al (2005) & 176 & CIS-R & $\geq 18$ & $106(60)$ \\
\hline Gunn et al (2015) & 24 & BSI-A & $\geq 13$ & $8(33)^{a}$ \\
\hline Hengartner et al (2015) & 259 & $\mathrm{MH}-\mathrm{CIDI}$ & NR & $54(20.8)$ \\
\hline Surratt et al (2012) & 562 & GAIN & $\geq 7$ & $230(40.9)^{\mathrm{a}}$ \\
\hline laisuklang et al (2017) & 100 & MINI & NR & $8(8)$ \\
\hline Ranjbar et al (2019) & 48 & SCID & NR & $11(22.9)^{b}$ \\
\hline Rossler et al (2010) & 193 & MH-CIDI $2 \cdot 1$ & NR & $65(33.7)$ \\
\hline Surratt et al (2005) & 278 & BAl & $\geq 16$ & $147(52.9)^{\mathrm{a}}$ \\
\hline Ghose et al (2013) & 100 & HADS & $\geq 8$ & $44(44)^{a}$ \\
\hline \multicolumn{5}{|c|}{$\begin{array}{l}\text { a: Reporting of absolute number is missing and was therefore calculated from the reported percentage; b: Reporting of percentage is missing and was } \\
\text { therefore calculated from the reported absolute number }\end{array}$} \\
\hline \multicolumn{5}{|c|}{$\begin{array}{l}\text { GHQ: General Health Questionnaire; HADS: Hospital Anxiety Depression Scale; SCL-AS: Symptoms Checklist-90-R Anxiety Subscale; CIS-R: Clinical } \\
\text { Interview Schedule-Revised: BSI-A: Brief Symptom Interview-Anxiety; WHO MH-CIDI: WHO Mental Health Composite International Diagnostic Interview; } \\
\text { GAIN: The Global Appraisal Individual Needs; MINI: International Neuropsychiatric Interview; SCID DSM-IV: Structured Clinical Interview for DSM-IV; BAl: } \\
\text { Beck Anxiety Inventory }\end{array}$} \\
\hline
\end{tabular}

\section{Figures}




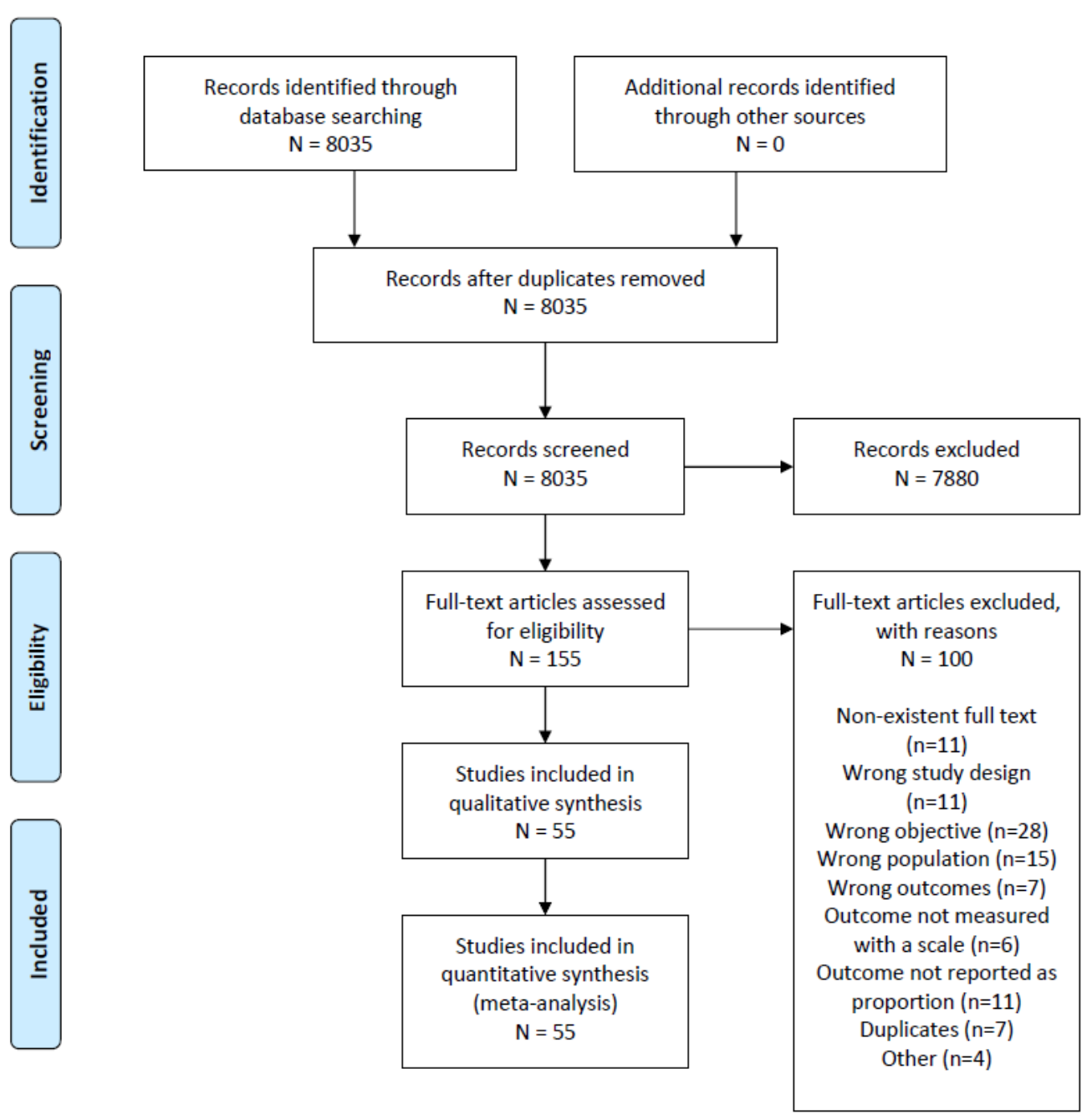

\section{Figure 1}

Study selection flow diagram 
Group

Suicide ideation

Overall

Last Year

Ever

Suicide attempt

Overall

Last Year

Ever

\section{Depression}

Overall

Self-reported scales

Rater-administered scales

\section{Post Traumatic Stress Disorder}

Overall

Self-reported scales

Rater-administered scales

$\mathrm{N}$ of Studies

$\mathbf{n} / \mathbf{N}$

$\mathbf{I}^{\wedge} \mathbf{2}$

Proportion

$95 \%$ CI

$18 \quad 2201 / 8107 \quad 98.91$

$9 \quad 1358 / 4366 \quad 98.99$

$\begin{array}{lll}9 & 843 / 3741 \quad 98.14\end{array}$

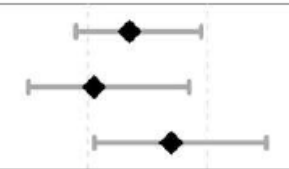

0.27

$[0.18,0.39]$

0.21

$[0.1,0.37$ ]

$0.34 \quad[0.21,0.5]$

20

$\begin{array}{lll}16 & 1249 / 6166 & 97.62 \\ 6 & 337 / 2614 & 91.11 \\ 10 & 912 / 3552 & 97.82\end{array}$

0.2

$[0.13,0.28]$

$0.13 \quad[0.09,0.18]$

$0.25 \quad[0.15,0.38]$

$10+912 / 3552-97.82$

$40 \quad 7248 / 17581 \quad 99.18$

$33 \quad 6967 / 16642 \quad 99.21$

$7 \quad 281 / 939 \quad 96.89$

$281 / 939 \quad 96.89$

$0.44 \quad[0.35,0.54]$

$0.48 \quad[0.38,0.58]$

$0.28 \quad[0.13,0.51]$

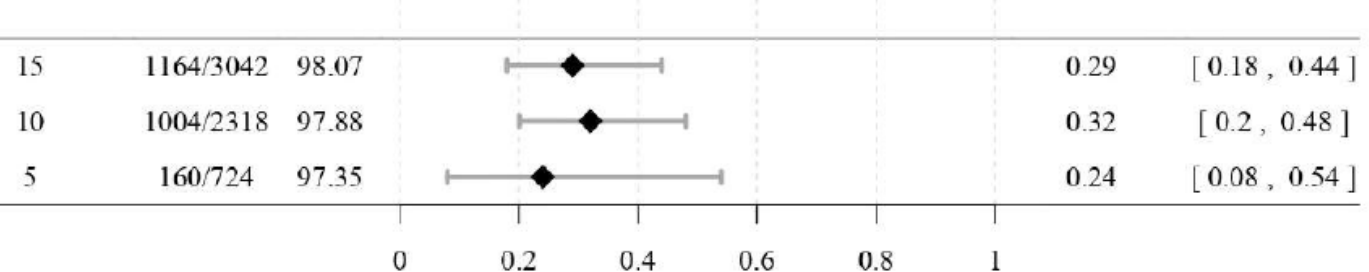

\section{Figure 2}

Pooled prevalence of suicide ideation, suicide attempt, depression and post-traumatic stress disorder (PTSD) among included studies 